\title{
J.A.P. Paré
}

\section{Meinhard Kneussl}

Affiliations: Wilhelminenspital Wien, Medical University of Vienna, Vienna, Austria.

Correspondence: M. Kneussl, Wilhelminenspital Wien, Medical University of Vienna, Vienna, Austria. E-mail: meinhard.kneusslawienkav.at

On February 24, 2013, Jules Arthur Peter Paré MDCM, BSc, FACP, Professor Emeritus of Medicine, McGill University (Montreal, QC, Canada) died at 95 years of age in Montreal after a long and full life.

Dr Paré grew up in Montreal and received his MD degree from McGill University in 1943. He trained in Internal Medicine and Respiratory Medicine at McGill and in 1948-1949 was a postdoctoral fellow in Chest Medicine at the Massachusetts General Hospital, Harvard Medical School in Boston, MA, USA. He then returned to Montreal, where he spent the duration of his career. In 1975, he became Professor of Medicine at McGill, and between 1975 and 1983 was the combined Respiratory Division Head of all McGill teaching hospitals (Royal Victoria Hospital, Montreal General Hospital, Montreal Chest Hospital and Jewish General Hospital).

Professor Paré was a masterful clinician and teacher and influenced two generations of respiratory physicians at McGill and these have, in turn, affected Respiratory Medicine across all parts of the globe. With his friend, Dr Robert Fraser, a chest radiologist at McGill, he published their textbook, Diagnosis of Diseases of the Chest, in 1970, which would be "the bible" in chest medicine for decades, not only for clinicians but also for radiologists and thoracic surgeons. With the book a medical best seller, Fraser and Pare soon realised that they had developed a unique approach to the diagnosis of diseases of the chest that was based on an initial systematic description of the chest radiographic abnormalities. At that time (late 1960s) there was only one comprehensive textbook of respiratory medicine, which was edited by Dr Gerald Baum, and amazingly it only contained four chest radiographic images.

Their landmark textbook was translated into many languages. Additional editions of the book, which grew to a four-volume reference work, were published in 1977, 1988 and 1999. In the later editions, Paré and Fraser recruited their sons, Dr Richard Fraser, an outstanding pulmonary pathologist, and Dr Peter D. Paré (Junior), a respiratory physiologist and researcher, as co-authors. For the last edition, they also involved Drs Neil Coleman and Nestor Müller. Diagnosis of Diseases of the Chest has influenced pulmonary physicians worldwide and brought notoriety to McGill's Respiratory Division.

Although primarily a clinician teacher, Dr Paré was involved in important clinical research. He and his colleague Dr B. Rose were among the first in the world to use corticosteroids in the treatment of asthma [1]. $\mathrm{He}$ and his colleagues were the first to describe pulmonary and retinal talcosis secondary to the intravenous injection of talc-containing drugs [2,3]. Along with his cardiovascular colleagues he published the first comprehensive description of hereditary hypertrophic cardiomyopathy [4]. The description was based on a large French Canadian kindred and the diagnosis was made using clinical examination and ECG. When molecular genetic techniques became powerful enough to discover causative genes, investigators at Harvard contacted Dr Paré, and he organised recontacting the patients and their extended families. The ensuing study was the first to identify a gene for hypertrophic cardiomyopathy. It is fitting that Dr Parés last publication, nearly 30 years after the description of hereditary cardiovascular dysplasia, appeared in The New England Journal of Medicine [5].

Dr Pare is remembered best as a clinician diagnostician, with a large expertise and experience in chest radiology, and as a great teacher. I had the privilege of doing a postdoctoral fellowship in the Meakins Christie Laboratories at McGill in 1977 and fondly remember the weekly Pulmonary, Clinical, Radiologic, Physiologic and Pathologic rounds that he initiated with his colleagues Drs Robert Fraser, Peter Macklem and Whitey (William) Thurlbeck. These conferences are still called "Paré Rounds", and have served as a model for teaching created in many other centres. 


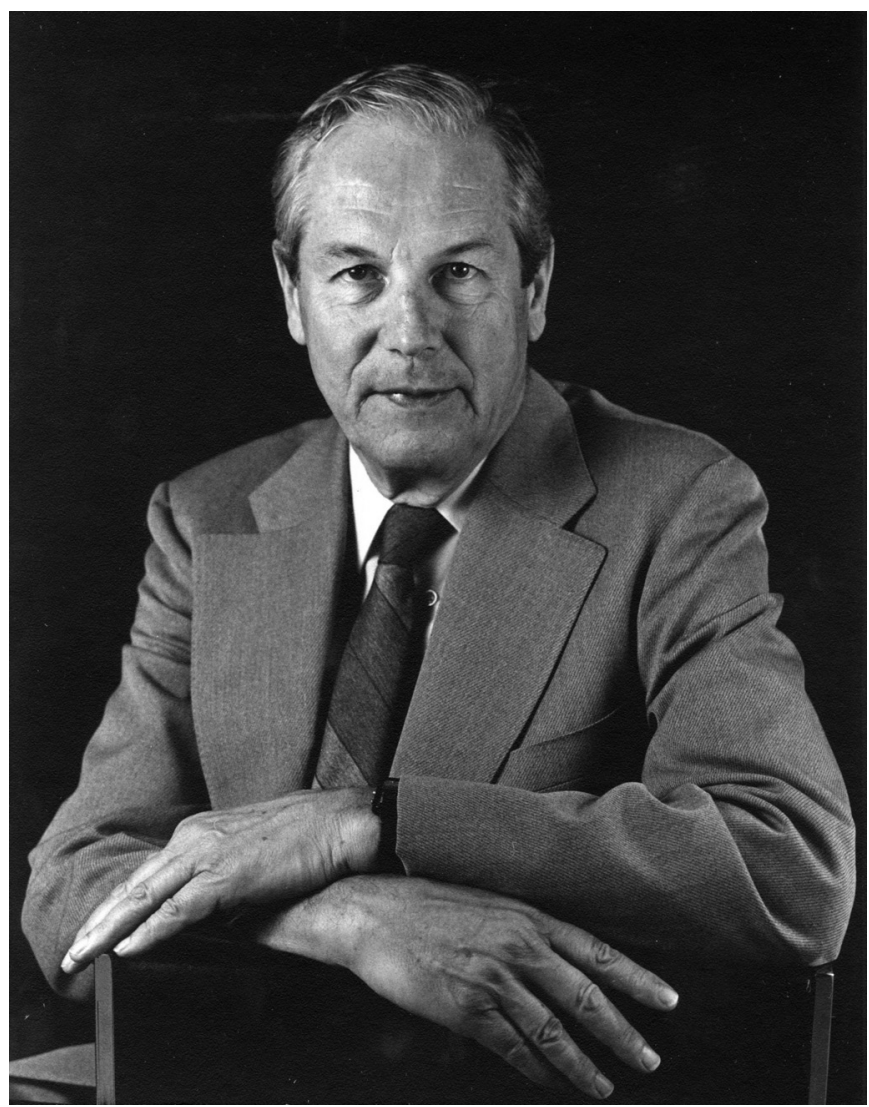

When you stood at the view box reviewing radiographs at Pare Rounds, he would listen as you would attempt to describe some obvious abnormality. If you were getting it wrong, he would not wait for you or want to make you feel small - you already felt small and everybody saw that you were wrong. Instead, he would say "Take a step back". After a while you saw what everybody else in the room now saw was obvious, and you would learn by describing it. We not only learned clinical radiology, we learned a method of teaching. When I was completely wrong, Dr Paré would simply say to me "I wouldn't have thought that". He never put you down. I try to keep that in my mind when I teach my students, residents and fellows.

Dr Paré was a colleague and mentor to David Bates, Jonathan Meakins, Robert Fraser, William (Whitey) Thurlbeck, Margo Becklake, Peter Macklem, Joseph Milic Emili, Rudy Dollfuss, Nickolas Anthonissen, James Hogg, Ann Woolcock, Gerhard Sybrecht, Ludwig Engel, Nai-San Wang, Paul Despas, Manuel Cosio, Paul Rivington, Richard Boucher, Dean Schraufnagel, Charis Russos, Peter D. Paré Jr, Jim Martin, Neil Coleman, David Eidelman, Dick Pardy, Marc Decramer and many more who were attracted to the Respiratory Division or the Meakins Christie Laboratories at McGill University.

Dr Paré remains the model for teaching with a humorous, gentle and always encouraging style. He received the Distinguished Achievement Award of the American Thoracic Society in 2011. McGill University was flying its flag at half-mast on March 4, 2013, when a celebration was held at the Medical Faculty of McGill in recognition of Professor Dr J.A. Peter Paré.

\section{REFERENCES}

1 Fyles TW, Paré JAP, Rose B. The effect of corticotropin and cortisone on respiratory function in bronchial asthma. J Allergy 1995; 26: 340-358.

2 Paré JAP, Fraser RG, Hogg JC, et al. Pulmonary "mainline” granulomatosis: talcosis of intravenous methadone abuse. Medicine 1979; 58: 229-239.

Murphy SB, Jackson WB, Paré JAP. Talc retinopathy. Can J Ophthalmol 1978; 13: 152-156.

4 Paré JAP, Fraser RG, Pirozynski WJ, et al. Hereditary cardiovascular dysplasia. A form of familial cardiomyopathy. Am J Med 1961; 31: 37-62.

5 Jarcho JA, McKenna W, Paré JAP, et al. Mapping a gene for familial hypertrophic cardiomyopathy to chromosome 14q1. N Engl J Med 1989; 321: 1372-1378. 